Sven-Erik Hansén

Professor at the Faculty of Education

Åbo Akademi University

\title{
Liselott Forsman
}

Researcher and teacher educator at the Faculty of

VISIONS

Conference

2011:

Teacher

Education

Education

Åbo Akademi University

Jessica Aspfors

Doctoral student and teacher educator at the Faculty of Education

Åbo Akademi University

Marina Bendtsen

Doctoral student and teacher educator at the Faculty of Education

Åbo Akademi University

\section{Visions for Teacher Education - Experiences from Finland}

\begin{abstract}
The study of teacher education in different countries reveals that many basic problems seem quite similar, although we might use different ways of categorizing and labeling the constituent elements. These differences can be specific to certain contexts, at least partly due to different traditions. To allow educationalists to understand and learn from each other on a global level, it is important to find ways of communicating these issues. The present article provides a meta-analysis of various empirical studies conducted by the authors and other Finnish researchers. The discussion entails exposing the plan and composition of characteristic features constituting Finnish teacher education. However, its ambition goes beyond describing the state of affairs: Despite a unanimous appreciation of its design, both nationally and abroad, Finnish teacher education is facing many kinds of tensions and challenges, which we in the following characterize as dilemmas. The overall aim of this article is to discuss some of these dilemmas, and also to suggest some possible ways of dealing with these. We will discuss four types of dilemmas: (1) the organization of teacher education in higher education institutions and its internal organization, (2) the relationship between general and subject-specific didactics, (3) a research-based approach versus practice-oriented approaches, and (4) the dilemma of the transition from education to work.
\end{abstract}

\section{Introduction}

The study of teacher education in different countries reveals that many basic problems are quite similar, although we use different ways of categorizing and 
labeling the constituent elements. These differences can be specific to certain contexts, and are, at least partly, due to different traditions. For educationalists to understand and learn from each other on a global level, it is therefore important to find ways of communicating these traditions. In 2006-2007 a ministerial committee was appointed and given the task of visualizing Finnish teacher education up to the year 2020 (Lärarutbildning 2020, 2007). One of the early decisions of this committee was to state that no major changes should be carried out with regard to the basic structure of Finnish teacher education. Since this structure was introduced close to three decades before, this, at first, stands out as a very conservative decision. However, this decision can also be seen as quite natural and reasonable: In 1979, Finnish teacher education was upgraded to the university level for all categories of teachers, and the design was completely integrated within the university examination system. This means that, except for pre-school teachers and some branches of teachers for vocational education institutes, the requirements for all categories of teachers is a Master's degree. Building on this, the vision of the committee was to outline the future development for teacher education within the current framework of Master's level studies. Many of the visions of the committee deal with challenges that are familiar to teacher educators in many countries. They are aimed at finding new solutions to old problems, to establishing new paths when the old ones no longer lead to the stated aims, and to create the appropriate means in changing external conditions. Among these are the questions of how to strengthen the knowledge base for teacher education and how to combine elements from different programmes into an integrated whole.

Our discussion starts with a brief overview of the design and some characteristic features of Finnish teacher education. However, the ambition goes beyond describing the state of affairs: Despite a unanimous appreciation of its design, both nationally and abroad, Finnish teacher education is facing many kinds of tensions and challenges which we, as mentioned, have characterized as dilemmas.

A dilemma points to a binary way of thinking, though not in the sense of a sharp contradiction between two conceptual pairs or opposing standpoints, as in the case of dichotomies. Instead, dilemmas represent challenges where a tension, or patterns of tensions, can be found between various views and standpoints. Thus, for our discussion here, dilemmas form patterns of tensions that constitute the content and the structure of teacher education.

\section{The aim}

Against this background, the overall aim of the present article is to identify some of the most common dilemmas, to suggest some possible ways of dealing with them and to highlight them with examples from Nordic teacher education 
discourse. The illustrating examples reflect our "own” national design, but still mirror one particular solution regarding common frameworks. The story will be a pragmatic one, and the view taken will be wide. This means that the design of Finnish teacher education at large is in focus and supported by questions such as: "Why has an advanced academic standard for the whole approach been prioritized?" and "What does it mean in our interpretation to claim that professional growth and professionalism should be based on academic knowledge creation through independent practitioner research, i.e. writing theses at Bachelor's and Master's level?” In this context, knowledge creation refers to all means aimed at expanding student teachers' knowledge and understanding of the teaching profession and the teacher's ability to act.

The reasons we have chosen to discuss the design of Finnish national teacher education and its dilemmas are manifold. One relates to the fact that the Finnish PISA success over almost a decade has created wide international curiosity as to which factors might have played a role in this success story. Despite limited evidence-based knowledge of these reasons, one of the factors that has been suggested is the design of Finnish teacher education. Another is the academic status of the Master-based teacher education, fully integrated into the university system. This is in immediate relation to the ambition of teacher education of having a research-based approach. Together, these factors all point to this basic foundation. This is because, within research on teacher education, teachers' expertise has been singled out as the main factor in explaining educational results (Darling-Hammond \& Bransford, 2005).

\section{Dilemmas}

Within the context of teacher education several kinds of dilemmas can be identified. Those we have chosen to focus on represent phenomena which, from our perspective, are central, current and widely discussed. Our analysis will examine four dilemmas: (1) the organization of teacher education in higher education institutions and its internal organization, (2) the relationship between general and subject-specific didactics, (3) a research-based approach versus practice-oriented approaches, and (4) the dilemma of the transition from education to work.

\section{The Dilemma of Organizing Teacher Education}

Teacher education is interdisciplinary by nature. The resulting interplay between different scholarly disciplines and the specific requirements of teacher education creates an organizational dilemma: how do we organize a multidisciplinary teacher education in institutions of higher education? The challenging issue centres on the question of how the organization will have the capacity to utilize the high levels of academic competence needed in a wide variety of disciplines. 
It also requires extensive human and economic resources, which is not always understood in the competition between disciplines. Furthermore, the design calls for an organization which enables an on-going and close connection between theoretically and practically oriented parts of the qualification process. The interdisciplinary nature challenges the question of how to establish coherence, continuity and a well-elaborated progression in the approach of complexity. Who is to take responsibility for keeping all the parts together? This problem has been apparent in evaluation projects of, for instance, Norwegian and Swedish teacher education.

The complexity manifests itself in several ways. For instance, no grand theory of teacher education exists which could provide an overall guiding principle for organizing teacher education in higher education institutions. A brief look into the situation in the Nordic countries reveals various organizational solutions: In an evaluation of Norwegian teacher education (Evaluering av allmennlcererutdanningen i Norge 2006, NOKUT), three basic models were identified for compulsory-school teacher education. In Figure 1, the structures of these models are illustrated.
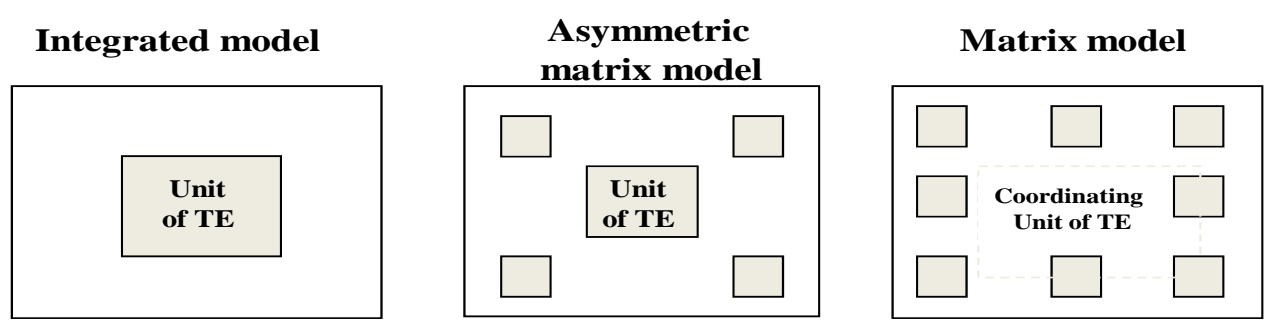

Figure 1 Models for organizing teacher education in higher education institutions

In the Integrated model, teacher education is organized as a separate and integrated unit characterized as a strong, independent, complex and multidisciplinary organization. From a student teacher perspective, the qualification process is permeated by a conscious striving to develop a strong teacher identity. Subject didactics are particularly emphasized, whereas the position and function of pedagogy varies despite a well-framed organization, which, in fact, provides good prerequisites. However, in several cases the evaluations have pointed to problems concerning the level of academic competence in different subjects and subject didactics, particularly in small institutions.

The Asymmetric matrix model means that part of teacher education is located in one unit, whereas the rest is localized in different subject-matter departments. This model opens up the possibility of utilising academic subject-matter competence outside the core unit of teacher education. Naturally, subject-matter studies are emphasized, which entails a risk of fragmentation. Evaluations 
suggest that in this model the teacher identity seems to be more nurtured by subject matter compared to in the integrated model.

The Matrix model represents an extreme in the sense that teacher education is mainly decentralized into subject-matter departments, whereas teacher education as a unit is reduced to an administrative centre with the task of coordinating courses and other activities. In this model, subject-matter competence is also given high priority, while teacher education tends to have a weak position, which is reflected in the marginalized role of pedagogy in particular.

In relation to the above models, Finnish teacher education can roughly be characterized as belonging either to the Integrated or the Asymmetric matrix model. For some categories of teachers, for instance class teachers in the lower grades of comprehensive school, organization follows the integrated model, whereas subject teachers are qualified according to the Asymmetric matrix model. Thus, Finnish teacher education faces similar problems to the ones discussed above.

The presentation and discussion of the three models show that conceptually there are various ways of organizing teacher education, and that each of them has its advantages and disadvantages. Although the models can be regarded as theoretical constructs, they still contain an important message: Organizing teacher education in institutions of higher education cannot be reduced to merely a technical or practical issue. The model of organization is an important ideological choice and an educational policy issue reflecting value-laden priorities. This is because the way we organize teacher education will have consequences for the professional identity of teachers, and in a long-term perspective also for the students' learning, personal growth and future.

\section{The Dilemma of General and Subject-Specific Didactics as Binary Pairs}

The dilemmas within this area are complex, manifold and partly related to the organizational structure previously discussed. The scope of general didactics is difficult to clearly define and cannot easily be distinguished from pedagogy. Broadly speaking pedagogy, as a discipline, covers a wider view of school and education compared to general didactics, which is oriented towards the teaching and learning process (Kansanen, Hansén, Sjöberg \& Kroksmark, 2011). The main dilemma is probably the one related to the question of how to define general didactics and subject-specific didactics, and how to establish and maintain a functional division between the two fields. It is therefore necessary to start from a definition of how the two fields can be defined and understood in one particular context. We will attempt to scrutinize the two concepts of general and subject-specific didactics as binary pairs partly positioned on the same continuum.

In Finland, the position of general didactics is relatively strong and indisputable compared to the situation in our neighboring countries, where 
general didactics seems to have an unclear and diffuse position within teacher education (Evaluering av allmennlcererutdanningen i Norge 2006, NOKUT; Uppföljande utvärdering av lärarutbildningen i Sverige. Swedish National Agency for Higher Education, Report 2008: 8R.) The Bologna process provided a possibility to reconsider and redefine both the function and the content of general didactics.

Figure 2 shows how the outlines for the content of general didactics can be categorized into the following five orientations: societal, individual, social, didactic and research orientation.

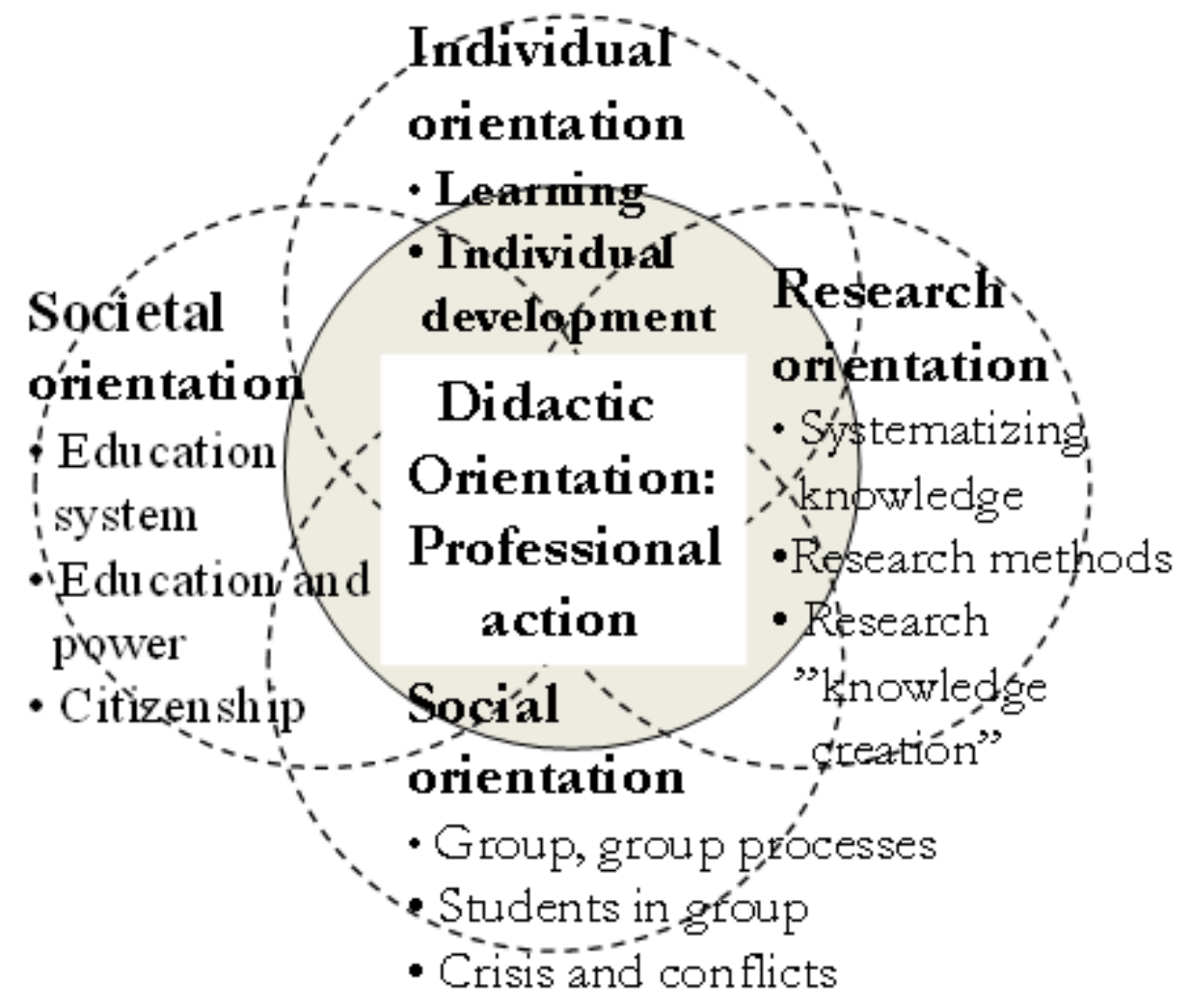

Figure 2 General didactics as an arena for knowledge creation

Societal orientation: This orientation captures the school as a societal organization and the complex relationship between school and society. Schools in the Nordic countries are public, and have the responsibility for societal reproduction and renewal drawing upon general didactics together with societal subject matters. This comprises socialization into new societal norms and cultural traditions. Providing students with the knowledge and skills they need in order to function in society still remains the responsibility of the school.

Individual orientation: Educational activities are also directed towards learning and influencing people, despite taking place in collective contexts. For instance, Biesta (2006) refers to and analyses Kant's individual view of educating a democratic person able to utilize his/her capacity for the common good. The individual orientation is closely connected with educational psych- 
ology and places the learning individual in focus. The orientation contains intertwined perspectives concerning the individual's intellectual, emotional and psycho-motoric development, together with current theories about learning during different phases of the individual's life.

Social orientation: Teachers need profound knowledge and understanding of the actions of individuals in groups, i.e. the social dynamics of groups, in and outside school. The social orientation is manifold and deals with relations and individuals as members of social communities characterized by verbal communication. School-based curriculum work is the common responsibility of all members of the teaching staff at a school, and they are required to coordinate their activities in order to develop and sustain a well-functioning school. Another community is constituted by outside partners such as parents.

Research orientation: The motive for a research orientation is linked to the view of professional qualifications. The orientation is both implicitly and explicitly present in the program, and forms the foundation for teachers' work. In the Finnish approach it is considered that teacher education itself can be developed only through continuous and comprehensive high quality research. This is implicitly aimed at permeating the whole program, with the ambition of qualifying teachers through the development of their ability for critical reflection, and the ability to systematically scrutinise their daily work (cf. Niemi \& Jakku-Sihvonen, 2006). The task of the research orientation is to support teachers' didactic actions and to develop stimulating contexts for learning. The explicit part of this orientation comprises carrying out independent studies by using scholarly methods for the writing of a Bachelor's and Master's thesis. This work is supported by courses in research methodology, and seminars around the theses, as well as on individual supervision and guidance.

Didactic orientation: This orientation concerns teachers' actions in their daily work, where the teachers develop, through continuous decision-making in connection to teaching and learning, their ability to bind together practice and theory, to integrate pedagogical knowledge and subject knowledge with appropriate didactic knowledge and skills. Such knowledge and skills operate on a more general level, which is the responsibility of general didactics, and on a subject-specific level, which is the responsibility of subject didactics. Parallel to the practical action level within a normative curricular framework, the program for teacher education contains theory-driven activities within a descriptive framework (Kansanen, 2002). Activities at this level aim at supporting student teachers in developing their thinking, and reflection and research activities are considered central means of meeting these requirements. This orientation particularly takes into consideration the requirements of a more holistic view, the need for which evaluations of teacher education in recent years in some of the Nordic countries have pointed out (Evaluering av allmennlcererutdanningen i Norge 2006, NOKUT; Uppföljande utvärdering av lärarutbildningen i Sverige. Swedish National Agency for Higher Education. Report 2008: 8R). 
Thus, subject-specific didactics also play a crucial role in the qualification process, and student teachers obtain and expand their ability to act within different subject areas (cf. Ongstad, 2006). Furthermore, it is interesting to note how changing societal needs, together with developments in educational research in the different subject fields, may change the interplay between the fields of general and subject-specific didactics. They may eventually also lead to changed responsibilities between the two. For example, as the notion of citizenship is taking on a wider meaning than the national one, educational researchers within the field of foreign language education have advocated that more responsibility for the developing view of global citizenship can be taken on by the different language subjects. This requires a more systematic and integrated approach to the cultural dimension in the foreign language classroom, notably a more affectively-related and process-oriented view of culture. This means that the cultural aspects of any foreign language taught in schools can no longer be looked upon merely as the passing on of a static list of facts and the behaviors of an allegedly homogeneous, cultural group. Instead, emphasis is put on the promotion of value-related aspects such as a respect for differences in general, as well as on skills related e.g. to observing and interpreting behavior. This is to enable students to interact with people from many different origins and backgrounds (see also e.g. Forsman, 2010a, 2010b).

The challenge here becomes how to coordinate the functional division between the two areas of didactics in an appropriate manner. Different evaluations of teacher education programs clearly show that many institutions face problems in this respect, and student teachers complain about the lack of coordination and cooperation among teacher educators (Evaluering av allmennlererutdanningen i Norge 2006, NOKUT; Uppföljande utvärdering av lärarutbildningen i Sverige. Swedish National Agency for Higher Education. Report 2008: 8R). The connection seems to have been weak, or more or less nonexistent among the representatives of scientific disciplines, subject-specific didactics, general didactics and school subjects in the practice schools. The whole chain can be very weak, meaning that teacher education takes place within isolated cells spread out among faculties and departments. To some extent, the dilemma is related to the fact that when teacher education is decentralized to different faculties and departments, i.e. follows the Matrix model, it causes structural dilemmas. However, in some cases the dilemmas seem to be mainly attitudinal. The construction or the struggle over the composition of teacher education programs deals with the kind of values we attach to various parts constituting the program.

\section{The Dilemma of a Research-Based Approach for Teacher Education}

As stated above, Finnish teacher education represents an approach constructed in a scholarly manner. Its ambition, like all university-based education, is to construct a research-based program and to actively participate in knowledge 
creation. The approach is described as an organizing principle that combines studies with research, and the academic value of the chosen approach is considered to be dependent on its closeness to research (Kansanen, 2006). The underlying ambition is to educate reflective professional teachers - not professional researchers - who are able to understand and act, and to justify their actions by drawing upon research-based evidence and thinking (Niemi \& JakkuSihvonen, 2006; Kansanen, 2006). A significant feature characterizing this approach is reflection as a tool to gain knowledge and understanding of action and interaction in the teaching-studying-learning process.

Conceptually, reflection is closely connected to a research-based approach because it is based on openness and curiosity that contribute to active participation in the adventures of creating and exploring the world of learning and knowledge. At a more pragmatic level, a research-based approach is aimed at assisting student teachers in internalizing an open-minded and inquiry-oriented attitude towards their work, and in becoming able to give pedagogical reasons for their daily actions. The latter involves the ability to deconstruct problems and to reconstruct new appropriate solutions (cf. Niemi \& Jakku-Sihvonen, 2006). Reflection is thus aimed at providing a stable ground for educational decision-making that is based on rational argumentation (Kynäslahti, Kansanen, Jyrhämä, Krokfors, Maaranen \& Toom, 2006).

What kind of dilemmas may occur within a research-based approach? The dilemmas are complex and manifold in this area as well, and we will briefly discuss features we see as the most visible and common.

The first deals with the question of how to carry out and position explicit research activities within a program which, by tradition, has been experiencebased, and which is characterized by a hands-on approach focusing more on the daily activities in classrooms and schools than on academic lectures or seminars. Another way of approaching this dilemma is by asking how a research-based approach could be motivated or defended.

During the last decades, teacher education has increasingly been attached to, or integrated into, institutions of higher education. In Finland a structurally drastic step in this direction was taken in 1974, when the main part of all teacher education was transferred to universities, although some parts, e.g. class-teacher education, retained a special position outside the university degree system. The demand from the 1970s was to connect university-conducted pedagogical studies on theory and practice with subject-matter studies. The development of teacher education continued, and already by 1979, teacher education, with only a few exceptions, had become fully integrated in the university degree system (Niemi \& Jakku-Sihvonen, 2006). From that year on, the main route to qualification was a five year, full-time program leading to a Master's degree. Despite the fact that several decades have passed since this integration, teacher education is still struggling for a stable and recognized position within the academic world. 
In other words, this dilemma can be described as an ongoing, but slowly diminishing tension between the two cultures which still seem to characterize teacher education. One stems from the tradition of regarding practice as a highway to "the making" of a teacher, a culture of practice that has been vividly exposed when programs have been constructed or reconstructed. The other, the culture of academia, has claimed that the positive potential of practice can only be utilized if it is firmly rooted in a research-based approach. Berliner (2005) claims that research in teacher thinking is inseparably tied to teachers' actions. This process involves theorization on the basis of practice as well as turning theory into practice. Theory is embedded in practice and practice in theory, i.e. we theorize on the basis of practice and practice our theories (Carr, 1986; Hansén \& Sjöberg, 2006). Successfully balancing these two aspects of the same totality can be regarded as a quality indicator of teacher education, and serves as a means of qualifying professional teachers. A group of Finnish researchers has developed a model which aims at describing how a dynamic relationship between the two cultures could be established (Kansanen, Tirri, Meri, Krokfors, Husu \& Jyrhämä, 2000).

The model comprises three levels: one action level and two thinking levels. The action level starts from practice, or action, where actions take place as preactivities, e.g. lesson planning. Next, the teaching situation itself is characterized by interaction with students, and post-activities are where the actions are evaluated. Post-activities are important because they will develop student teachers' ability to critically examine actions, widen their consciousness of possible choices, and together with theory-oriented studies provide a basis for developing so-called object theories.

Theories on thinking level one offer useful object theories directed at understanding teachers' actions in schools and classrooms. However, at this level they are limited to distinct and well-framed objects and to finding ways of solving immediate and concrete problems. Thus, object theories are theories for educational practice and represent a situated, though generative knowledge and understanding. However, a research-based approach is not content with object theories on thinking level one.

Thinking level two can be described as a meta-theory level where object theories can be combined into wider and more abstract conceptual models. Theories at this level represent general knowledge creation and can therefore provide pedagogy as a discipline with new knowledge. The elaboration of an ability to act on this level implies a capacity to think or reflect critically, and aims at supporting student teachers in an independent and scholarly approach to their work. In other words, they are expected to be able to apply their knowledge and understanding from both theory and practice-oriented activities to their daily work (cf. Moon, 2008). Thus, developing an ability to act on thinking level two is not an abstract activity far removed from the daily work of teachers. On the contrary, this level is directed towards understanding and managing action in a 
professional way, towards the ability to deconstruct problems and to reconstruct models for solving them, and towards being able to make sense of and to practically utilize a common conceptual language characterized by clearly defined notions. Writing a Master's thesis plays, in this respect, an essential role for building level two thinking capacity among student teachers and, in the practical prolongation, to develop the ability to make decisions based on rational arguments.

Closely attached to the first dilemma is another that can be described as a structural and economic one, concerning the conditions for educational research within the scholarly field. As already mentioned, research forms the foundation for teachers' work and teacher education, and it can only be developed further through additional research. Calderhead and Shorrock (1997) claim that research on teacher education has not been a major theme within the field, although the situation is now improving. There are, for instance, several international journals and conferences discussing and disseminating research findings on teacher education However, the research foundation remains relatively weak, and, from a Finnish point of view at least, we have to gain more solid knowledge and develop a deeper, research-based understanding of our task (Lärarutbildning 2020, 2007).

\section{The Dilemma of the Transition from Education to Work}

The fourth dilemma concerns the transition from being a student teacher to starting work as a qualified teacher, in other words the teacher socialization process. How this transition progresses depends on a number different factors and how these, in turn, interact. In our analysis we will focus on three issues that have emerged as significant in our own, as well as in the research of others. These issues are connected to 1) education, 2) school as a workplace and 3) the profession. A fourth, highly influential factor is the characteristics of the individual teacher, i.e. a person's personality, values, beliefs and expectations. As the individual characteristics so intricately permeate and determine the direction of the socialization process as a whole, we will treat this factor as an integrated aspect of the three issues in focus here.

The discussion of this dilemma will for the most part be illustrated with Finland-Swedish research findings from an on-going study by Bendtsen (forthcoming) on the transition from student to newly qualified subject teacher $(\mathrm{N}=20)$.

With regard to issues connected to education, we can note that both the organization of teacher education and the focus of the studies have an influence on the teachers' experiences as NQTs (newly qualified teachers).

While class-teacher education is organized according to the previously mentioned integrated model, subject teachers study their subjects in a subject department and take their teacher education courses in a teacher education department (the Matrix model). Thus, the subject teachers are socialized into at 
least two different disciplinary traditions, and they themselves will have to make the necessary connections and distinctions between the two. This dual focus can be noticed in their perceptions of their roles as teachers. Some see themselves primarily as language teachers, whereas others consider themselves to be teachers who happen to teach languages (Aspfors, Bendtsen, Hansén \& Sjöholm, 2011a).

One of the main concerns of the subject teachers in our study is that of finding their role as teachers, i.e. knowing what you are, what you want to be and what you should be. Being a NQT almost inevitably involves questions of teacher identity and a cluster of concerns that follow in the wake of that. The reasons behind these concerns are many; some relate to the new teachers' developing sense of self-confidence, some seem to emanate from the working context and some, again, are connected to the educational background. Examples of the latter concern among the teachers in our study is e.g. their struggle to find a satisfactory balance between the dual responsibilities of representing and teaching the subject on the one hand, and caring for the pupils on the other (Aspfors et al., 2011a).

Another issue relates to the focus of teacher education being highly researchbased. One of the central aims of the Master-based teacher education in Finland is, as discussed earlier, that teachers internalise and apply a research-oriented approach to their work (Niemi \& Jakku-Sihvonen, 2006). The question is whether this approach and focus during teacher education has a lasting effect on teachers' way of thinking and acting in their work. In her longitudinal study of the transition from student teachers to NQTs, Nyman (2009) found that some of the NQTs applied tools of critical reflection in their work and were thus able to benefit from what they had learned in their pedagogical studies. Others, again, did not reflect on what they did, and returned to models of teaching from their own school days instead. Thus, in the current situation the outcome seems largely dependent on the individual teacher's capacity to apply critical thinking and reflection to understanding their work. The question is whether something could and should be done to enhance the effects of education among the latter group of teachers, possibly in the form of continued support during the induction phase.

Our second point concerns issues connected to the school as a workplace. In a society characterized by rapid change and global influences, new teachers entering school have to come to terms with sometimes conflicting values and educational beliefs. The mismatch can be between the values of teacher education and those of the school, or between the new teacher's own ideals and those of the other staff, or between values expressed by different members of staff within the same school. Herein lies another reason as to why new teachers struggle with questions of teacher identity and with finding their role as teachers. 
The question of school culture is also related to the school as a workplace. The different school cultures experienced by the subject teachers in our study are predominantly described as individualistic (Aspfors et al., 2011a; cf. Nyman, 2009). In such a culture, where there is little or no insight into what goes on in the classroom next door, it is very difficult for new teachers to develop professionally. Teachers have to manage with what they have and when they are left without support, they may revert to models from their own school days (Bramald, Hardman \& Leat, 1995).

Our third point of focus involves issues connected to the profession. The teaching profession is in many ways an elusive profession. There are no set working hours required, no clear job description as to what tasks are required and what can be seen as less important. It is largely up to the individual teacher to define what constitutes a job well done. Because of this, teachers, and new teachers in particular, struggle with setting limits to their own commitment and between their private and professional lives (Aspfors, Bendtsen \& Hansén, 2011).

The profession can also be described as complex, in that there are many things that need to be simultaneously taken into consideration. The hectic pace of the work day combined with lack of routine does not allow much time for reflection. With the focus on survival, and without time for reflection, it is very difficult to develop professionally. In connection with this, new teachers struggle with balancing between different aspects of their work, as well as with coming to terms with not being able to realize some of their ideals (Aspfors, Bendtsen, Hansén \& Sjöholm, 2011b).

The three issues depicted above serve to illustrate the problem of a missing link between teacher education and working life. The need to support new teachers is a widespread international challenge. Increasing research evidence shows that NQTs need support during the first phase of their career, especially in developing a strong professional identity as well as self-efficacy as teachers. Indeed, experiencing mastery during the transition from education to work contributes to reducing attrition. This is extremely important as an increasing number of teachers in western society tend to leave the profession during the first years (cf. Alhija \& Fresko, 2010; Smethem, 2007; Tynjälä \& Heikkinen, 2011). The situation is particularly alarming as studies have found that the most capable and successful teachers are the ones who are leaving (Rots et al., 2007). For quality reasons, as well as societal and economic reasons, it is therefore important to retain teachers in the profession.

From an international perspective the practices of supporting teachers vary a lot. In some countries the support consists of statutory induction programs as part of the qualification process (cf. UK, Canada, New Zealand). In other countries the support is organized as voluntary, in-service training. Nevertheless, many countries still fail to offer adequate support for their new teachers (cf. OECD, 2005). Since 2010 the national initiative for supporting new teachers in 
Finland is peer-group mentoring (PGM). This is implemented through a national consortium project called Osaava Verme, comprising all the teacher education departments of the universities and vocational teacher education institutions in Finland $^{1}$. The PGM model was developed during 2005-2010 through research projects involving the Finnish Institute for Educational Research and teacher educators in Finland. It is rather unique as it, in contrast to many other induction and mentoring programs, has no elements of assessment, standardization or control. Instead, PGM affords means for both new and experienced teachers to collaborate, reflect and learn together in a supportive environment. As such, the approach is in line with general pedagogical trends in Finland emphasising a high level of teacher autonomy (Aspfors \& Hansén, 2011; Heikkinen, Jokinen \& Tynjälä, 2008, 2012).

\section{Concluding remarks}

Finnish teacher education is widely considered to have an excellent design due to its combination of academic and theoretical studies with extensive practice, thus providing appropriate conditions for the qualification of professional teachers. However, it has also been criticized for being rigid, conservative and old-fashioned, due to the fact that its basic structure has more or less been unchanged since 1979. Nevertheless, the structure has been further confirmed by a Ministry working group in 2007 in their work with providing a perspective of teacher education up to the year 2020. The Finnish solution has thus been to prioritize a research-based teacher education at Master's level prior to a continuing, systematized and integrated further education. Not until recently has Finland started to give prominence to the induction phase, and offer support for new teachers through peer-group mentoring. Accordingly, Finland differs from many other countries where the reform processes have been very fast and whole concepts have been replaced within quite limited time frames.

Finnish teacher education has received much praise. Despite this, it still struggles with several types of dilemmas. Some of them are related to the way teacher education is organized within the universities, others to the missing link between education and work.

Such dilemmas are certainly challenges that need to be taken seriously. Increased awareness of existing tensions may provide a point of departure for turning these tensions into visions, and gradually evolving these into contributing to the further development of teacher education. Awareness of the dilemmas may guide educators when targeting measures to be taken. Furthermore, the identification of dilemmas will contribute to maintaining a holistic perspective to teacher education, and thus prevent us from losing control through too narrow focus on the numerous details of such a complex endeavour. An analysis of various and seemingly contradictory patterns may thus lead to a 
deepened understanding of the dynamics of these multi-layered processes. (Sjöholm \& Hansén, 2007)

The revision of Finnish teacher education in 1979 contained several visions aimed at solving problems and reducing dilemmas, and in the course of time many of these have found their solutions. The revision also happened to become more or less identical with the Bologna design for higher education Master's programs that appeared almost three decades later. The only major difference is that in the new design the Bachelor's degree has been emphasized. However, alongside this slow reform process, a fast process conducted by teacher education itself is going on: courses are continuously being redesigned, new courses are replacing old, new literature is being introduced, while measures are being taken to integrate theoretical and practical elements of the program. Our experiences and observations support the fact that Finnish teacher education at present is in a dynamic, and in many ways, constructive phase. Despite a range of dilemmas requiring considerable effort to handle, the first years' stumbling blocks to a fully university-integrated route have gradually been replaced by more mature solutions, in particular to the initial problems of making a researchbased approach an integrated part of the professionalization process.

\section{References}

Alhija, F., \& Fresko, B. (2010). Socialization of new teachers: Does induction matter? Teaching and Teacher Education 26, 1592-1597.

Aspfors, J., \& Hansén, S-E. (Eds.). (2011). Gruppmentorskap som stöd för lärares professionella utveckling. Helsinki: Söderströms.

Aspfors, J., Bendtsen, M., \& Hansén, S-E. (2011). Nya lärare möter skola och klassrum. In SE. Hansén, \& L. Forsman (Eds.), Allmändidaktik - vetenskap för lärare (pp. 331-353). Lund: Studentlitteratur.

Aspfors, J., Bendtsen, M., Hansén, S-E., \& Sjöholm, K. (2011a). Evolving views of the teaching profession - Voices from newly qualified subject teachers and class teachers. Paper presented at the ECER conference in Berlin, September 13-16, 2011.

Aspfors, J., Bendtsen, M., Hansén, S-E., \& Sjöholm, K. (2011b). Evolving views of the teaching profession - Voices from student teachers and newly qualified teachers. In U. Lindgren, F. Hjardemaal, K. Sjöholm, \& S-E. Hansén (Eds.), Becoming a teacher Nordic Perspectives on Teacher Education and Newly Qualified Teachers (pp. 23-46). Vasa: Åbo Akademi, Faculty of Education.

Bendtsen, M. (forthcoming). Professional development- evolving views in the transition from student teacher to newly qualified teacher (doctoral thesis, working title). Vasa: Åbo Akademi, Faculty of Education.

Berliner, D.C. (2005). The place of process-product research in developing the agenda for research on teacher thinking. In P.M. Denicolo, \& M. Kompf (Eds.), Teacher thinking and professional action (pp. 3-15). London: Routledge.

Biesta, G. (2006). Bortom lärandet. Demokratisk utbildning för en mänsklig framtid. Lund: Studentlitteratur.

Bramald, R., Hardman, F., \& Leat, D. (1995). Initial teacher trainees and their views of teaching and learning. Teaching and Teacher Education, 11(1), 23-31.

Calderhead, J., \& Shorrock, S.B. (1997). Understanding teacher education. Case studies in the professional development of beginning teachers. London: Falmer. 
Carr, W. (1986). Theories of theory and practice. Journal of Philosophy of Education, 20(2), 177-186.

Darling-Hammond, L., \& Bransford, J. (Eds.). (2005). Preparing teachers for a changing world: What teachers should learn and be able to do. San Fransisco: John Wiley \& Sons.

Evaluering av allmennlcererutdanningen i Norge 2006. Del 1: Hovedrapport; Del 2: Institusjonsrapporter. NOKUT.

Forsman, L. (2010a). On the changing role of English language education: Promoting respect for difference in the language classroom. Intercultural Education, 21(6), 505-518.

Forsman, L. (2010b). EFL Education in the new millennium: Focus on the promotion of awareness of difference and diversity. Scandinavian Journal of Educational Research, 54(5), 501-517.

Hansén, S-E., \& Sjöberg, J. (2006). Didaktik i lärarutbildningar. In S. Ongstad (Ed.), Fag og fagdidaktikk i læererutdanning. Kunskap i grenseland (pp. 258-273). Oslo: Universitetsforlaget.

Heikkinen, H.L.T., Jokinen, H., \& Tynjälä, P. (2008). Reconceptualising mentoring as a dialogue. In G. Fransson, \& C. Gustafsson (Eds.), Newly Qualified Teachers in Northern Europe. Comparative perspectives on promoting professional development (Research publication 4, pp.107-124). Gävle: University of Gävle.

Heikkinen, H.L.T., Jokinen, H., \& Tynjälä, P. (2012). Supporting learning at work through peer-group mentoring. London: Routledge.

Kansanen, P. (2002). Didactics and its relation to educational psychology: problems in translating a key concept across research communities. International review of education, 48(6), 427-441.

Kansanen, P. (2006). Constructing a research-based program in teacher education. In F.K. Oser, F. Achtenhagen, \& U. Renold (Eds.), Competence oriented teacher training. Old research demands and new pathways (pp. 11-22). Rotterdam: Sense publishers.

Kansanen, P., Tirri, K., Meri, M., Krokfors, L., Husu, J., \& Jyrhämä, R. (2000). Teachers' Pedagogical Thinking: Theoretical Landscapes, Practical Challenges. New York: Peter Lang.

Kansanen, P., Hansén, S-E., Sjöberg, J., \& Kroksmark, T. (2011). Vad är allmändidaktik? In S-E. Hansén, \& L. Forsman (Eds.), Allmändidaktik - vetenskap för lärare (pp. 29-50). Lund: Studentlitteratur.

Kynäslahti, H., Kansanen, P., Jyrhämä, R., Krokfors, L., Maaranen, K., \& Toom, A. (2006). The multimode programme as a variation of research-based teacher education. Teaching and Teacher Education, 22, 246-256.

Lärarutbildning 2020. Niemi, H., Hansén, S-E., Jakku-Sihvonen, R. \& Välijärvi, J. (2007). Undervisningsministeriets arbetsgruppspromemorior och utredningar 2007: 44. Helsingfors.

Moon J. (2008). Critical thinking. An exploration of theory and practice. London: Routledge. OECD (2005). Teachers Matter. Attracting, developing and retaining effective teachers. Retrieved October 21, 2011, from http://www.oecd.org/document/52/0,3343,en_2649_201185_34991988_1_1_1_1,00.html

Ongstad, S. (2006). Fag i endring. Om didaktisering av kunnskap. In S. Ongstad (Ed.), Fag og fagdidaktikk i lærerutdanning. Kunskap i grenseland (pp. 19-57). Oslo: Universitetsforlaget.

Rots, I., Aelterman, A., Vlerick, P., \& Vermeulen, K. (2007). Teacher education, graduates’ teaching commitment and entrance into the teaching profession. Teaching and Teacher Education, 23(5), 543-556. 
Sjöholm, K., \& Hansén, S-E. (2007). Developing teacher professionalism. Dynamics of dichotomies in Finnish teacher education. In U. Lindgren (Ed.), A Nordic perspective on teacher education in a time of societal change. Contributions from a Nordic conference that focused on the professional teacher role (pp. 45-64). Umeå: Department of Swedish and Social Sciences, Teacher Education, Umeå University.

Smethem, L. (2007). Retention and intention in teaching careers: Will the new generation stay? Teachers and Teaching: Theory and Practice, 13(5), 465-480.

Tynjälä, P., \& Heikkinen, H. (2011). Beginning teachers' transition from pre-service education to working life. Zeitschrift für Erziehungswissenschaft, 14(1), 11-34.

Uppföljande utvärdering av lärarutbildningen i Sverige. (2008). Swedish National Agency for Higher Education. Report 2008: 8R.

\footnotetext{
${ }^{1}$ For more information see www.osaavaverme.fi
} 